\title{
Penanganan Sampah Secara Partisipatif Di Desa Salut Kecamatan Narmada Kabupaten Lombok Barat
}

\author{
Lukman Hakim \\ Fakultas Ekonomi dan Bisnis Universitas Mataram
}

Corresponding email:

\section{Info Artikel}

Kata Kunci:

Harga lingkungan, Willingness

To Pay (WTP), partisipasi, Collective Action (CA)

\section{ABSTRAK}

Riset ini bertujuan untuk mengetahui (1) besarnya kesediaan membayar (willingness to pay, WTP) untuk mencegah menurunnya kualitas lingkungan, (2) partisipasi masyarakat dalam mengatasi masalah sampah, dan (3) memahami proses terbangunnya partisipasi masyarakat dan mengidentifikasinya dengan suatu model pendekatan / konsep yang ada.

Harga lingkungan ditetapkan berdasarkan musyawarah warga; baik menyangkut besaran/nilai moneter, siapa yang konsumennya (beneficieris), mekanisme transaksi, periodisasi/siklus, maupun tata cara untuk mengurangi pencemaran. Hasil musyawarah menyepakai retribusi (harga) lingkungan sebesar Rp 2.000; dibayar setiap minggu; transaskinya dilakukan oleh petugas yang akan mendatangi rumah setiap warga. Tingkat partisipasi masyarakat dalam mengatasi masalah sampah cukup tinggi, yaitu sebesar $60.5 \%$ (297 RT dari $491 \mathrm{KK}$ ).

Pendekatan collective action menhgasilkan simulasi; faktor kuat yang mempengaruhi partisipasi masyarakat dalam mengatasi masalah sampah adalah manfaat yang dirasakan oleh warga. Rumah/halaman menjadi bersih, tidak ada sampah yang bertebaran, dan tidak ada tumpukan sampah di pinggir jalan, sungai menjadi bersih, dan warga tidak repot membuang sampah di sungai.
\end{abstract}

\section{ABSTRACT}

\section{PENDAHULUAN}

a. Latar Belakang

Kegiatan simultan dalam ekonomi yang utama adalah produksi, konsumsi, dan distribusi. Ketiganya menghasilkan residu sebagai hasil ikutan (by product) berupa limbah buangan (pollutant) yang tidak diinginkan karena menyebabkan polusi. Produksi umpamanya, selain menghasilkan produk, pula dihasilkan limbah buangan; konsumsi, selain menghasilkan nilai guna juga sampah; dan pada distribusi barang menghasilkan energi dan emisi carbon dioksida $\left(\mathrm{CO}_{2}\right)$. Pertumbuhan ekonomi dan dan bertambahnya jumlah penduduk, menyebabkan bertambahnya limbah buangan yang dialirkan ke alam. Jika kuantitas sampah melebihi kapasitas asimilasi lingkungan, maka akan menimbulkan pencemaran lingkungan.

Pada saat yang sama lingkungan dibutuhkan karena mampu memberikan jasa lingkungan berupa penyangga kehidupan (natural life support system) seperti: kenyamanan, air, bahan baku dan mentah, energy, dll. Dengan demikian, lingkungan/ sumber alam merupakan "asset" yang harus dipertahankan keberadaannya untuk mendukung aktivitas produksi dan konsumsi. Untuk menjaga dan 


\section{Elastisitas - Jurnal Ekonomi Pembangunan}

Vol. 2 No. 1, Maret 2020

memulihkan lingkungan yang tercemar, menghindari penciutan serta penurunan kualitas sumber alam, maka harus diadakan biaya yang dapat dianggap sebagai biaya perlindungan. Secara konsepsional dan operasional estimasi biaya-biaya kerusakan lingkungan dianggap sulit, adalah mungkin mengidentifikasikan beberapa komponen dan menampilkan dampak biaya pengendalian pencemaran pada harga. Konsep yang lazim digunakan adalah willingness to pay, WTP, yaitu besarnya kesediaan membayar masyarakat/konsumen untuk mencegah kerusakan atau memperbaiki lingkungan.

Lingkungan alam merupakan barang public, karena adanya ekternalitas yang ditimbulkan oleh aktivitas produksi dan konsumsi. Eksternalitas muncul bilamana activitas seseorang pelaku ekonomi mempengaruhi produksi atau kepuasan (utility) pelaku lainnya tanpa mendapat konpensasi/ganti rugi. Limbah (padat ataupun cair) yang dialirkan ke sungai dapat menyebabkan pencemaran sehingga airnya tidak dapat dipakai oleh masyarakat sekitar. Tumpukan sampah rumahtangga dapat mengganggu kenyamanan masyarakat sekitar. Ditinjau dari reaksi makhluk hidup, hal ini berpengaruh terhadap penurunan kesejahteraan (kepuasan/utility) yang diekspresikan dengan rasa tidak suka, tidak senang, menderita, prihatin, risau, gelisah.

Riset akan dilaksanakan di Desa Salut Kecamatan Narmada untuk menjawab persoalan tentang penanganan sampah limbah rumahtangga. Di desa ini, beberapa inisiatif dalam mengatasi masalah sampah mengalami pasang-surut, dalam arti solusi untuk pemecahan masalah tidak dapat bertahan/berlangsung lama. Fenomena ini menarik untuk dicermati; dari perspektif keswadayaan masyarakat pedesaan. yaitu: adanya kesadaran terhadap lingkungan, inisiasi menjadikan masalah penanganan sampah menjadi masalah kolektif, cara-cara yang ditempuh dalam mengatasi masalah lingkungan/penanganan sampah, mekanisme penetapan harga lingkungan, dll.

\section{b. Rumusan Penelitian}

Berdasarkan pemaparan pada Latar Belakang, permasalahan risetnya adalah:

1) Faktor apa yang paling berpengaruh terhadap kesediaan membayar (willingness to pay, WTP) untuk mencegah menurunnya kualitas lingkungan.

2) Apa saja bentuk partisipasi dari masyarakat dalam mengatasi masalah sampah.

3) Bagaimana prosesnya bisa dijelaskan oleh suatu model pendekatan tertentu.

\section{c. Tujuan Penelitian}

Riset ini bertujuan untuk mengetahui:

1) Besarnya harga lingkungan dan mekanisme/proses terbentuknya harga tersebut.

2) Faktor yang paling berpengaruh terhadap kesediaan membayar (willingness to pay, $W T P$ ) untuk mencegah menurunnya kualitas lingkungan.

3) Bentuk partisipasi dari masyarakat dalam mengatasi masalah sampah.

4) Memahami proses terbangunnya partisipasi masyarakat dan mengidentifikasinya dengan suatu model pendekatan / konsep yang ada.

\section{TINJAUAN PUSTAKA}

a. Telaah Kosep

Subyek riset ini adalah sumberdaya lingkungan yang mengalami persoalan penurunan kualitas. Metode penilaian seberapa besar kerusakan yang terjadi dan berapa besar kesediaan orang untuk membayar harga lingkungan, digunakan metode tertentu (disajikan pada point selanjutnya). Kesediaan ini adalah konsekwensi logis dari keinginan untuk mendapatkan manfaat yang diperoleh dari lingkungan yang baik. Hal yang lebih penting adalah kesediaan ini merupakan bentuk kepedulian terhadap lingkungan dan partisipasi keswadayaan. Karenanya, point pentingnya adalah cara dan metode yang digunakan dalam membangun partisipasi masyarakat. Kajian ini lebih menarik, karena settingnya berada pada kajian sosial yang hubungannya dengan lingkungan bersifat 


\section{Elastisitas - Jurnal Ekonomi Pembangunan}

Vol. 2 No. 1, Maret 2020

fungsional. Pendekatan yang dilakukan adalah "Collective Action" (CA). Sementara riset teknis statistic dalam menghitung kerusakan lingkungan, hanya dipahami oleh kalangan terentu dan kurang bermanfaat dalam penyusunan kebijakan.

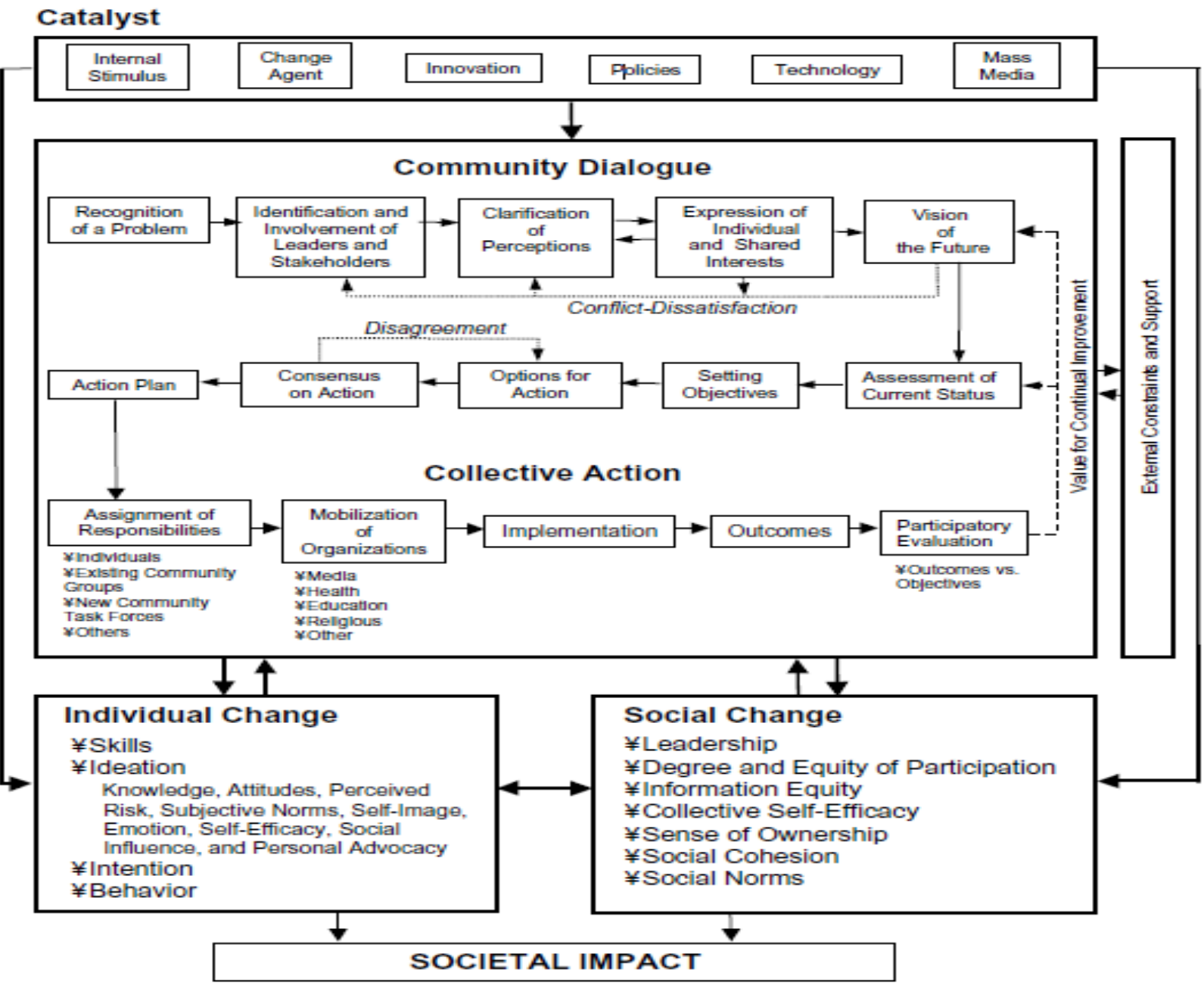

Sumber: Figueroa, et.al, 2002. p. 7

Gambar 1. Skema Model Collective Action

Pendekatan CA bersifat generic sebagai cara dalam mengatasi masalah-masalah sosial. Hal ini setidaknya terlihat dari beberapa riset yang telah dilakukan oleh berbagai pihak. Pendekatan ini oleh Wade (1987) digunakan pada kasus sumberdaya milik bersama (common property resources), dimana orang-orang menempatkan kerjasama dalam merumuskan regulasi dan implementasinya pada pengelolaan sumberdaya itu untuk mencegah terjadinya situasi 'tragedy of com- mon' akibat adanya eksploitasi berlebihan sejalan dengan naiknya permintaan.

Sebagai catatan, sumberdaya dikelompokkan menjadi 2 (dua) kategori: private property dan common property. Sumberdaya kategori pertama memiliki ciri penting antara lain hak kepemilikan yang syah dan memiliki regulasi yang jelas, karenanya akses penggunaan dan kontrol terhadap sumberdaya itu hanya pada pemiliknya. Sementara pada sumberdaya common property, kedua ciri ter- 


\section{Elastisitas - Jurnal Ekonomi Pembangunan}

Vol. 2 No. 1, Maret 2020

sebut (penggunaan dan control) tidak ada, karenanya seseorang tidak dapat dicegah untuk manfaatkannya (open access) yang berimplikasi pada jumlah orang yang memanfaatkan, cara dan alat yang dipakai. Contoh adalah sungai, sumberdaya perikanan laut, dan lainnya. Karenanya, cirri ini dapat menimbulkan tragedy atau mengancam kelestarian sumberdaya tersebut akibat terjadinya eksploitasi berlebihan sehingga stok (ikan) habis, terjadi kerusakan akibat cara-cara dan alat yang dipakai (bom ikan dan potas).

Demikian pula Dasgupta dan Beard (2007), melalui proyek the Urban Poverty Project (UPP) dari Bank Dunia, memakai pendekatan collective action untuk merespon bertambahnya angka kemiskinan di Indonesia akibat resesi ekonomi pada 1997. Pendekatan ini berkaitan dengan keterbatasan model topdown dalam perencanan pembangunan, dan mengupayakan adanya peningkatan kontrol masyarakat atas pembangunan, khususnya pada aspek perencanaan, implementasi dan alokasi sumberdaya (Bank Dunia menyebut strategi ini dengan term 'community driven development'). Proyek dilaksanaan di 1298 kelurahan dari daerah Yogyakarta dan Malang, dengan melibatkan badan keswadayaan masyarakat (BKD) setempat.

Aktivitas ekonomi selain menghasilkan produk, juga menyisakan residu berupa limbah atau emisi yang dialirkan ke lingkungan alam. Limbah semakin bertambah bila tujuan perekonomian menuntut adanya pertumbuhan output, disamping adanya kenaikan jumlah penduduk. Penumpukan limbah pada lingkungan dari aktivitas ekonomi dan konsumsi. Apabila daya rusak yang ditimbulkan oleh limbah (karena kuantitas limbah) melebihi kemampuan memulihkan dari lingkungan (assimilativecapacity) maka terjadi polusi yang mengancam kerusakan fungsi fisik dan mengurangi kenyamanan sehingga mengurangi kepuasan (Pearce, and Turner, 1990).

Gambar 2. Skema Produksi Sampah

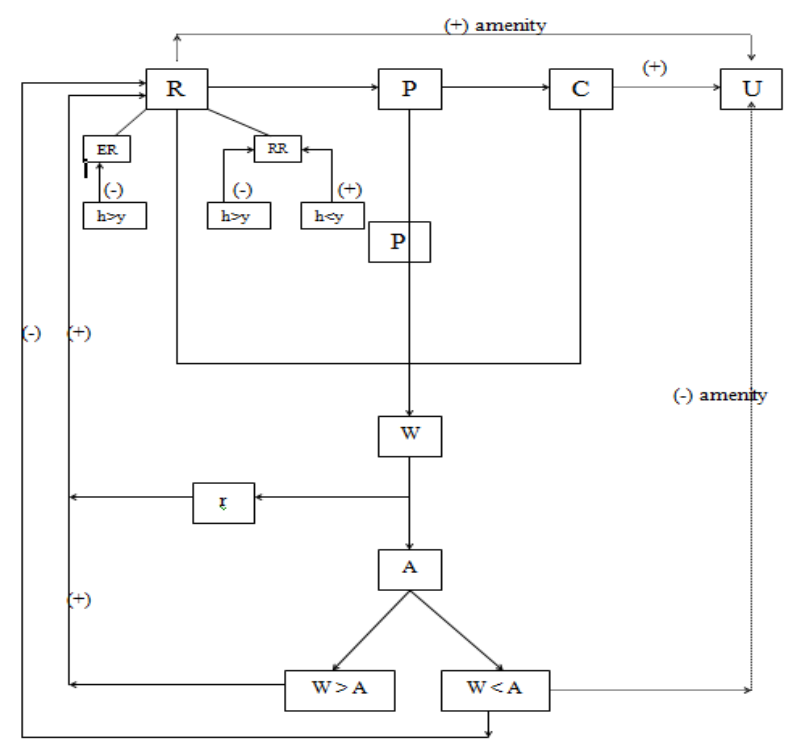

Sumber: Pearce, David W. and R. Kerry Turner. 1990. Economics of Natural Resources and The Environment. Harvester Wheatsheaf. London.

Selanjutnya, timgkat produksi (GDP) dan kemudian lain menentukan kesejahteraan, tergantung pada ketersediaan bahan mentah yang disediakan oleh alam, seperti energy dan barang-barang tambang. Selain itu, sumberdaya lingkungan juga memberikan jasa lingkungan berupa lingkungan yang nyaman, udara yang bersih, air, dan udara/suhu yang sejuk. Dengan demikian sumberdaya lingkungan merupakan asset untuk mendukung kemajuan ekonomi. Oleh karenanya, kelestarian sumberdaya ini sangat penting dipelihara. 


\section{Elastisitas - Jurnal Ekonomi Pembangunan}

Vol. 2 No. 1, Maret 2020

Gambar 3. Skema Sistem Ekonomi dan Lingkungan
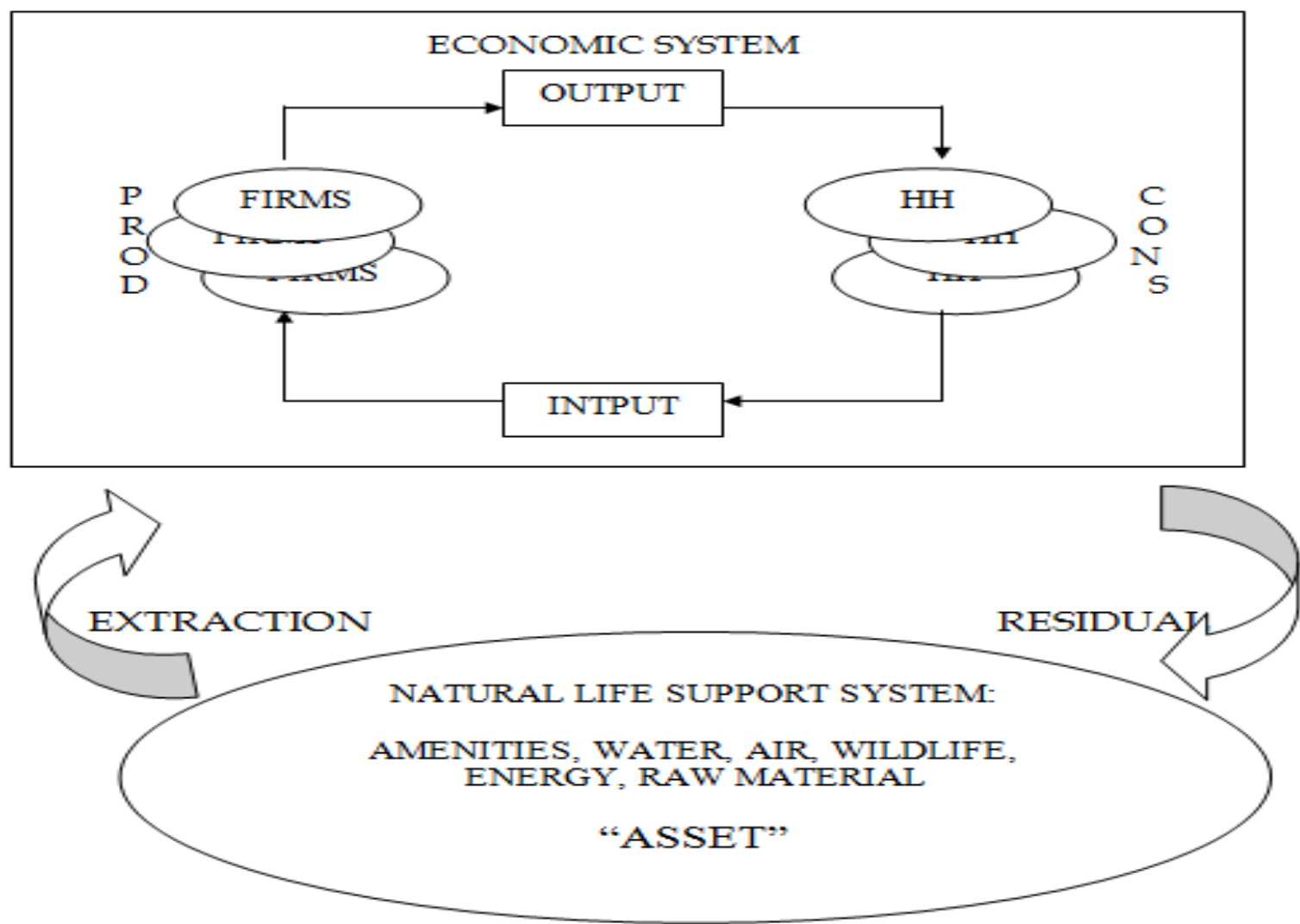

Sumber: Tietenberg, Thomas H. 1988. Environmental and Natural Resource Economics. Scott, Forestman and Company. London. p. 17.

Namun karena sumberdaya ini merupakan barang public, maka gangguan terhadap kelestariannya sangat rentan. Cirinya adalah non-excludable dan non-livalry (Howard, 2001; Leach, 2004; Myles, 2001). Dalam upaya pelestarian sumberdaya tersebut, perlu dilakukan penilaian terhadap potensi kerusakannya dan biaya perbaikan lingkungan dibebankan kepada pihak yang mendapatkan manfaat dari jasa lingkungan yang diberikan oleh sumberdaya tersebut.

\section{b. Konsep Kesediaan Untuk Membayar (Willingness to pay)}

Willingness to pay atau kesediaan untuk membayar adalah kesediaan individu untuk membayar terhadap suatu kondisi lingkungan atau penilaian terhadap sumberdaya alam dan jasa alami dalam rangka memperbaiki kualitas lingkungan. Dalam WTP dihitung seberapa jauh kemampuan setiap individu atau masyarakat secara agregat untuk membayar atau mengeluarkan uang dalam rangka memperbaiki kondisi lingkungan agar sesuai dengan kondisi yang diinginkan. WTP merupakan nilai kegunaan potensial dari sumberdaya alam dan jasa lingkungan (Hanley dan Spash, 1993).

Beberapa pendekatan yang digunakan dalam perhitungan WTP:

1) Menghitung biaya yang bersedia dikeluarkan oleh individu untuk mengurangi dampak negatif pada lingkungan karena adanya suatu kegiatan pembangunan. 


\section{Elastisitas - Jurnal Ekonomi Pembangunan}

Vol. 2 No. 1, Maret 2020

2) Menghitung pengurangan nilai atau harga dari suatu barang akibat semakin menurunnya kualitas lingkungan.

3) Melalui suatu survei untuk menentukan tingkat kesediaan masyarakat untuk membayar dalam rangka mengurangi dampak negatif pada lingkungan untuk mendapatkan lingkungan yang lebih baik.

\section{METODE PENELITIAN}

\section{a. Pemilihan Lokasi Penelitian}

Secara purposive dipilih Dusun Merce, Desa Salut Kecamatan Narmada sebagai lokasi penelitian. Dusun tersebut dipilih berdasarkan pertimbangan hanya dusun tersebut terdapat adanya penanganan masalah sampah secara kolektif dan partisipatif, tidak memiliki tempat pembuangan akhir (TPA) sehingga sampah menumpuk di rumah, di jalan, dan membuang sampah ke sungai. Sampah yang dibuang sungai mengakibatkan sampah menumpuk sehingga terjadi pendangkalan sungai, air sungai kotor, dan menimbulkan dampak pada bagian hilir karena sampah akan terbawa oleh aliran sungai. Alasan lainnya adalah adanya upaya kolektif untuk mengatasi masalah sampah walaupun belum kontinu, dimana tindakan kolektif tersebut ada kalanya timbultenggelam.

\section{b. Metode Pengumpulan Data}

Metode pengumpulan data dilakukan dengan cara survey, yaitu mengumpulkan data dari sebagian populasi yang dijadikan sampel. Populasi penelitian ini adalah seluruh warga yang yang ikut dalam program penanganan sampah di Dusun Merce, Desa Salut. Populasinya sebanyak 297 RT, dan sampelnya ditentukan sebesar $10 \%$ (30 RT). Data diperoleh dengan melakukan wawancara kepada kepala rumah tangga sebagai responden yang dipilih secara ramdom. Sebagai tambahan, responden dikunjungi di rumahnya, dan bila tidak berada di tempat maka akan digantikan oleh RT lain. Selain
RT, diwawancarai pula tokoh masyarakat setempat sebanyak 3 orang.

\section{c. Variabel Penelitian}

1) Harga lingkungan (hedonic price) adalah besarnya retribusi yang dipungut secara periodik yang ditetapkan berdasarkan kesepakatan.

2) WTP adalah besarnya nilai moneter lingkungan yang bersedia dibayarkan untuk mendapatkan manfaat/jasa lingkungan, dan atau untuk mencegah menurunnya kualitas lingkungan.

\section{d. Metode Analisa Data}

Data akan dianalisa secara kuantitatif dan kualitatif. Analisa kuantitatif menggunakan model regresi untuk mengetahui faktor yang berpengaruh kuat dalam keikut-sertaan warga dalam membayar retribusi sampah (atau kesediaannya membayar, WTP). Sedangkan analisa kualitatif menggunakan model Collective Action (CA), untuk menjelaskan proses dalam membangun kesepakatan kolektif.

Model regresinya adalah:

\begin{tabular}{|c|c|}
\hline $\mathrm{y}$ & $\begin{aligned}= & b 0+b 1 \times 1+b 2 \times 2+b 3 \times 3+b 4 \times 4 \\
& +b 5 \times 5\end{aligned}$ \\
\hline$y$ & $=$ frekweksi (kali) membayar sejak \\
\hline & $\begin{array}{l}\text { keikut-sertaannya dalam } \\
\text { program kebersihan lingkungan } \\
\text { dan karenanya harus membayar } \\
\text { retribusi sampah. }\end{array}$ \\
\hline DU & $=$ intersep \\
\hline $\mathrm{b} 1, \ldots \mathrm{b} 4$ & $\begin{aligned}= & \text { parameter untuk menilai kuat } \\
& \text { lemahnya pengaruh xi }\end{aligned}$ \\
\hline $\mathrm{x} 1$ & $\begin{aligned}= & \text { besarnya }(\mathrm{Rp}) \text { retribisi sampah } \\
& \text { yang dibayar per periode. }\end{aligned}$ \\
\hline$x 2$ & $=$ pendapatan bulanan RT. \\
\hline $\mathrm{x} 3$ & $\begin{array}{r}=\text { tingkat pendidikan yang } \\
\text { ditamatkan. Tingkat pendidikan } \\
\text { yang ditamatkan responden akan }\end{array}$ \\
\hline & $\begin{array}{l}\text { diberikan skor; } \\
\text { sekolah/tidak tamat } \mathrm{SD}=0, \mathrm{SL} \\
=1, \mathrm{SMP} / \text { sederajat }=2, \mathrm{SMA} \\
\text { sederajat }=3 \text {, dan Diploma } / \mathrm{PT}= \\
4 .\end{array}$ \\
\hline
\end{tabular}


Vol. 2 No. 1, Maret 2020

$\mathrm{x} 4$

= adanya manfaat yang dirasakan dibandingkan dengan beban ritribusi sampah. Perbandingan antara manfaat yang dirasakan dan beban retribusi sampah akan menghasilkan jawaban; apakah dirasakan ringan, sepadan, dan berat. Ketiga kategori jawaban itu diberikan skor, masing- masing adalah ringan $=3$, sepadan $=2$, dan berat $=1$.

x5 $=$ jumlah orang anggota $\mathrm{RT}$.

Model dasar CA relatif sederhana, karena hanya perlu melakukan dialog dan tindakan dari suatu kumunitas, dan prinsipnya adalah bersifat siklik.

Gambar 4. Skema Model Collective Action

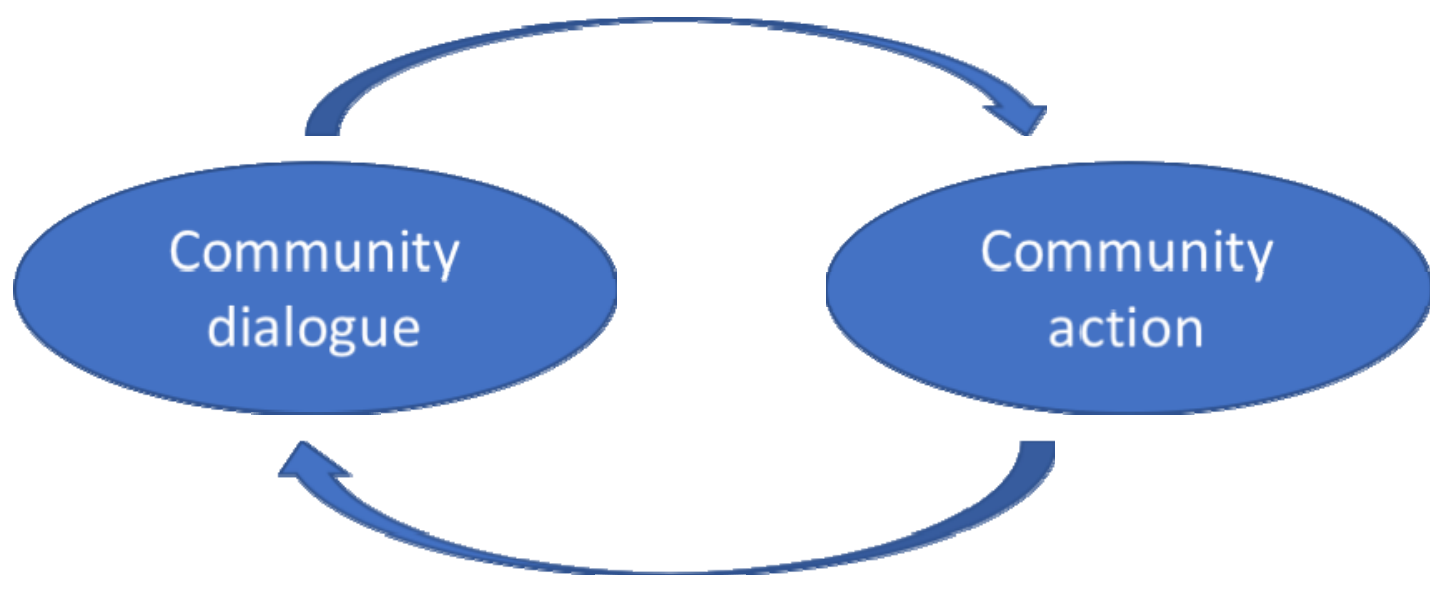

Dua aktivitas utama (yaitu dialog dan tindakan bersama) akan melahirkan kesepakatan dan hasil. Dialog akan menghasilkan kesepakatan dalam bentuk program kerja, dan tindakan kemudian memberikan hasil, dan hasil tersebut akan dievaluasi dalam aktivitas dialog. Demikian seterusnya sehingga bersifat siklik.

Secara lebih detail model tersebut dapat dikembangkan dalam suatu skema sebagai berikut. 


\section{Elastisitas - Jurnal Ekonomi Pembangunan}

Vol. 2 No. 1, Maret 2020

Gambar 5. Skema Model Pendekatan

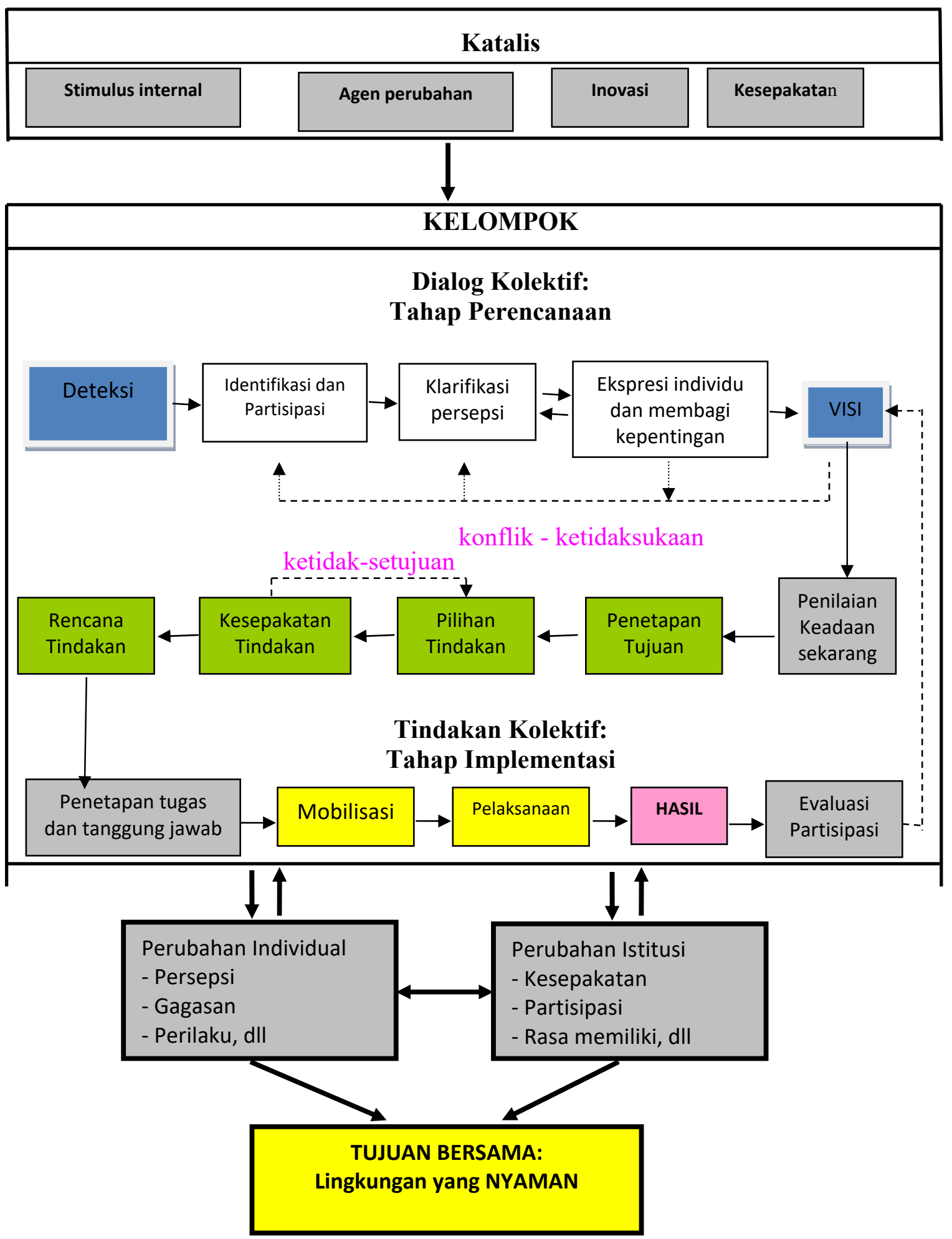




\section{Elastisitas - Jurnal Ekonomi Pembangunan}

Vol. 2 No. 1, Maret 2020

Seluruh rangkaian proses dan mekanisme yang dilakukan dikelompokkan dijelaskan dalam fase;

(a) persoalan yang dihadapi,

(b) penilaian keadaan lingkungan sekarang,

(c) membangun partisipasi, dan

(d) hasil.

\section{HASIL DAN PEMBAHASAN a. Data}

Seluruh responden dalam penelitian ini, berjenis kelamin laki-laki, dan telah berkeluarga. Rata-rata usia mereka adalah 44 tahun, dengan range antara 27-61 tahun, dan jumlah anggota RT sebanyak 3 jiwa. Artinya bahwa setiap RT responden terdiri dari ayah, ibu, dan satu orang anak. Tingkat pendidikan responden yang terbanyak tergolong masih rendah, dimana sebanyak $46,67 \%$ dari responden hanya tamat SD, tidak tamat SD, dan tidak sekolah; sebanyak $40 \%$ responden tergolong tingkat pendidikan menengah (SMP dan SMA), dan sebanyak $13,33 \%$ responden tergolong memiliki tinjgkat pendidikan tinggi (Diploma/PT).

Seluruh responden telah memiliki pekerjaan. Jenis pekerjaan responden yang terbanyak adalah buruh pasar $(33,33 \%)$, jenis pekerjaan responden yang kecil jumlahnya adalah penjahit $(3,33 \%)$, supir $(3,33 \%)$, dan swasta, yaitu jasa rental masing-masing sebesar 3,33\%. Responden yang memiliki pekerjaan sampingan sebanyak 33,33\%.

Rata-rata penghasilan responden per bulan sebesar Rp 1.539,17 ribu. Gap penghasilan responden sangat jomplang, dengan range yang cukup besar, dimana penghasilan terendah sebesar Rp 150 ribu per bulan dan tertinggi sebesar Rp 4.800 ribu per bulan. Jenis pekerjaan responden yang memiliki penghasilan kecil tersebut adalah buruh pasar, dan mereka tidak memiliki pekerjaan sampingan. Lokasi pasar dengan pemukiman mereka relatif dekat, yaitu kurang dari $1 \mathrm{~km}$.

\section{b. Hasil dan Pembahasan}

1) Penanganan Sampah

Produksi sampah per rumah tangga relatif kecil, yaitu rata-rata sekitar $0,46 \mathrm{~kg}$ per hari. Sampah yang dihasilkan adalah dalam kategori organik dan non-organik. Untuk jenis organik adalah pakaian bekas, dedaunan, dan limbah dapur seperti sayuran dan tulang. Sedangkan non-organik adalah plastik, karet, beling, dan besi. Jenis limbah plastik adalah tas kresek, gelas, botol, ember, dan mika. Jenis limbah karet antara lain sandal, ban sepeda, dan ban motor, ban mobil. Jenis limbah beling adalah gelas, piring, dan botol. Jenis limbah besi adalah kawat dan seng.

Mekanisme pengelolaan sampah di tingkat rumah tangga adalah sampah harian dikumpulkan ke dalam karung, tanpa membedakan kategori sampah organik maupun non-organik. Di dusun tersebut tidak memiliki tempat pembuangan sampah sementara. Jadi setiap RT responden memiliki tempat sampah (berupa karung plastic). Setiap Jumat pagi karung sampah tersebut diletakkan di pinggir jalan. Kemudian petugas kebersihan dari kecamatan akan mengambilnya, dimasukkan ke dalam truk, dan diangkut menuju ke tempat pembuangan akhir (TPA). Kumulatif sampah dari warga relatif kecil dibandingkan dengan kapasitas truk, sehingga semua sampah dapat diangkut satu kali.

Jumlah RT yang ikut dalam program penanganan sampah adalah sebanyak 60,5\% (297 RT dari 491 RT yang ada). Harga lingkungan yang dibayarkan oleh warga berupa retribusi sampah. Besarnya retibusi sampah adalah Rp 2000 per minggu. Besaran nominal retibusi itu ditetapkan berdasarkan kesepakatan dusun setelah melalui proses musyawarah antar warga. Kesepakatan tersebut bersifat sukarela dan mengikat bagi RT yang ingin masalah sampahnya ditangani oleh kelompok/petugas yang telah ditunjuk. Jumlah nominal retribusi itu adalah batas bawah retribusi namun jika ingin membayar lebih dari ketetapan sifatnya sukarela dan tidak mengikat. 


\section{Elastisitas - Jurnal Ekonomi Pembangunan}

Vol. 2 No. 1, Maret 2020

Dalam hal tata pembayaran, sebelum hari Jumat petugas akan mendatangi rumah warga untuk menarik retribusi. Dana retribusi akan dikumpulkan di ketua kelompok, dan selanjutnya dicatat oleh bendahara. Dana tersebut akan digunakan untuk membayar petugas kebersihan dari kecamatan. Jumlah yang dibayarkan sebesar Rp 300 ribu setiap satu kali angkut.

Faktor yang berpengaruh kuat terhadap keikut-sertaan warga mengikuti program kebersihan adalah manfaat yang dirasakan oleh warga. Hal ini ditunjukkan oleh hasil simulasi statistik dari data yang terkumpul. Berdasarkan hasil uji statistik nilai parameter (b) yang terbesar adalah b5, yaitu manfaat yang dirasakan dibandingkan dengan beban ritribusi sampah. Hasil selengkapnya adalah: $\mathrm{y}=2.379588-0.006397 \times 1-0.002202 \times 2-$ $1.747308 \times 3+33.62146 \times 4+2.047982 \times 5$

Manfaat itu adalah warga tidak lagi repot menangani sampahnya, dan lingkungan pemukiman mereka menjadi bersih dari sampah. Sebelum adanya program kebersihan, penanganan sampah dilakukan secara individu. Oleh karena dusun tidak memiliki TPS, maka oleh warga sampah ditimbun di halaman dan kemudian dibakar, atau ditanam di halaman rumah. Lainnya adalah dengan cara membuang sampah ke tempat-tempat umum seperti pinggir jalan dan sungai yang ada di kampung. Akibatnya lingkungan mereka menjadi kotor, sampah berserakan di pemukiman dan jalan, menumpuk di pinggir jalan dan menimbulkan bau busuk. Sementara sungai sebagai 'bak alam' tempat penampungan sampah, kondisi airnya kotor akibat sampah yang mengendap, dan daerah hilir ikut tercemar.

\section{2) Partisipasi}

Bagian ini berisi penjelasan tentang membangun partisipasi masyarakat dengan menggunakan model CA. Partisipasi masyarakat dalam penanganan sampah dapat dijelaskan dengan menggunakan model CA. Model pendekatan CA dapat digambarkan dalam skema berikut. 


\section{Elastisitas - Jurnal Ekonomi Pembangunan}

Vol. 2 No. 1, Maret 2020

Gambar 6. Skema Partisipasi Masyarakat Dalam Menangani Masalah Sampah

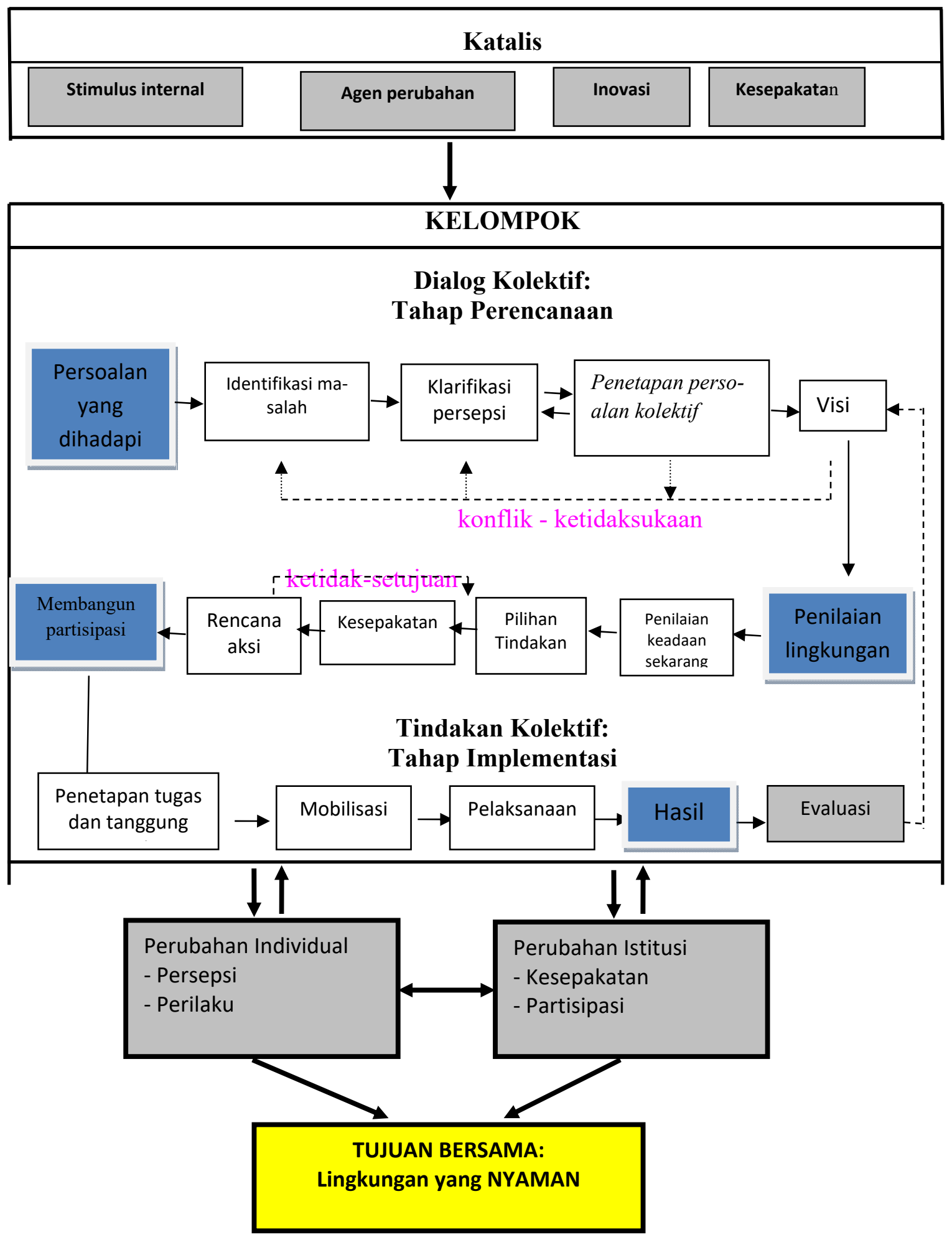




\section{Elastisitas - Jurnal Ekonomi Pembangunan}

Vol. 2 No. 1, Maret 2020

Berdasarkan skema pendekatan dalam memahami terbangunnya partispasi masyarakat, maka uraian akan dibagi dalam 4 fase, yakni:

(1) persoalan yang dihadapi,

(2) penilaian keadaan lingkungan sekarang,

(3) membangun partisipasi, dan

(4) hasil.

\section{(1) Persoalan yang dihadapi}

\section{- Identifikasi masalah}

Sebelum adanya program kebersihan kampung berupa penanganan sampah, kondisi lingkungan pemukiman penduduk adalah kotor, sampah bertebaran di di mana-mana. Jalan-jalan kampung, jalan umum kotor dengan sampah dan menimbulkan bau busuk, dan sungai tercemar oleh sampah. Kepala kampung merasa masalah ini tidak bisa dibiarkan berlarut-larut. Kemudian, masalah ini disampaikan secara personal kepada tokoh masyarakat setempat. Hasil pembicaraan tersebut kemudian disepakati untuk dibahas secara terbatas dengan tokoh masyarakat. Pertemuan dihadiri oleh 4 orang tokoh masyarakat, dan mereka sepakat untuk menambah jumlah peserta rapat pada pertemuan berikut dengan masing-masing membawa dua orang untuk dihadirkan dalam rapat.

Pada rapat kedua ini dibahas apa saja masalah yang dihadapi. Masing-masing peserta rapat diminta untuk menyampaikan satu masalah yang dihadapi berdasarkan pendapatnya. Masalah yang teridentifikasi dalam pertemuan itu antara lain:

- Masalah jamban kolektif, karena tidak setiap RT memiliki jamban

- Masalah pengasuhan anak, karena anakanak berkeluyuran tidak ada tempat publik untuk bermain

- Masalah pendidikan anak, perlu ada kelompok yang memberikan pendidikan baca Al Qur'an, pelajaran tertentu seperti Matematika, Bahasa Inggris untuk membantu anak di sekolah

- Masalah kesulitas modal usaha, dimana usaha yang banyak dikerjakan oleh warga adalah penjual tikar keliling
- Masalah sampah di lingkungan pemukiman, dimana sampah berserakan di lingkungan pemukiman, jalan, dan sengai

- Masalah belum ada perkumpulan anakanak remaja, seperti karang taruna, remaja mesjid, dan lainnya.

- Masalah kepengurusan masjid, adanya kevakuman dalam kepengurusan masjid.

- Masalah perlunya menata jalan lingkungan, dengan melakukan pemasangan pavin block.

- Dan lainnya

\section{- Klarifikasi persepsi}

Masing-masing peserta mengajukan satu permasalahan dengan menggambarkan kondisinya saat ini dan memberikan alasan terhadap masalah tersebut, beserta alternatif solusi yang mampu dilakukan berdasarkan persepsinya. Pada saat diskusi terhadap setiap masalah yang diajukan dan bagaimana cara mengatasinya, dengan tindakan apa yang perlu dilakukan, dan sumberdaya yang diperlukan, maka diskusi tidak menemukan solusinya realistik. Umumnya solusi yang diajukan mentok pada sumberdaya yang diperlukan untuk mengatasi masalah tersebut.

\section{- Penetapan persoalan kolektif}

Diskusi kemudian menawarkan perlu menetapkan satu persoalan yang dirasakan sebagai masalah bersama dan mampu dilaksanakan secara kolektif dengan sumberdaya bersifat partisipatif. Dari masalah yang ada, diputuskan masalah sampah sebagai masalah kolektif. Keputusan lainnya adalah perlu pertemuan berikutnya untuk membahas bagaimana cara menanganinya, seperti tindakan yang diperlukan dan mobilisasi sumberdaya.

- Visi

Visi lingkungan pemukiman yang terbangun pada pertemuan tersebut adalah warga menginginkan terciptanya lingkungan yang bersih dari sampah. Pelaksanaannya secara swadaya, karenanya setiap warga diimbau untuk ikut berpartisipasi. 


\section{Elastisitas - Jurnal Ekonomi Pembangunan}

Vol. 2 No. 1, Maret 2020

\section{(2) Penilaian lingkungan}

\section{- Penilaian keadaan sekarang}

Warga menyadari bahwa kondisi lingkungan pemukiman mereka belum bebas dari sampah. Sampah berserakan di halaman rumah warga, menumpuk dan berserakan di jalan sehingga jalan menjadi kotor dan menimbulkan bau busuk. Sampah di halaman rumah warga dibersihkan dengan cara mengumpulkan dan menimbunnya atau membakarnya. Cara demikian cukup merepotkan warga. Kadang-kadang warga di sekitarnya terganggu dengan asap dan bau busuk. Cara yang paling umum dilakukan adalah sebagian warga membuang dan menumpuk sampahnya di pinggir jalan, atau dibuang ke sungai. Cara demikian menyebabkan kumpulan sampah berderet di pinggir jalan, dan jika diterbangkan angin akan berserakan dan menimbulkan bau busuk. Kondisi lingkungan demikian mengganggu kenyamana warga.

\section{- Pilihan tidakan}

Hal kebersihan lingkungan, warga diminta untuk mengumpulkan sampahnya masing-masing dalam suatu wadah, dan perlu dibuang ke suatu tempat. Masalahnya adalah kampung tidak memiliki TPS, dan tidak tersedia bak truk dari kecamatan. Karena itu tindakan yang diperlukan adalah perlu meminta bak truk penampungan sampah, dan diangkut secara berkala. Untuk penyediaan bak truk sampah dan kelancaran pengangkutan maka petugas kebersihan (yaitu sopir truk sampah) perlu diberikan insentif.

\section{- Kesepakatan}

Oleh karena masalah kebersihan lingkungan pemukiman merupakan masalah bersama, maka perlu dibuat kesepakatan dalam menangani masalah sampah. Kesepakat (awiq-awiq) yang disetujui warga adalah:

1. Warga mengumpulkan sampahnya maingmasing dalam suatu wadah.

2. Dilarang membuang sampah ke jalan, dan atau ke sungai, serta diberikan sanksi jika membuang sampah ke jalan dan sungai.
3. Setiap jumat warga meletakkan sampah (harian yang terkumpul) dipinggir jalan agar mudah diangkut oleh petugas kebersihan kecamatan.

4. Setiap warga (yang ikut program penanganan sampah) membayar retibusi sampah sebesar Rp 2.000 per minggu.

\section{- Rencana aksi}

Setelah tersusun kesepakatan, tindak lanjutnya adalah penyusunan rencana aksi. Rencana aksi menyangkut:

1. Pembentukan kelompok/organisasi beserta strukturnya

2. Mekanisme penanganan sampah

3. Mekanisme pemungutan iuran retribusi

\section{(3) Membangun partisipasi}

- Penetapan tugas dan tanggung jawab

1. Penetapan tugas dan tanggung jawab dilakukan melalui penetapan kepengurusan dan tugas-tugasnya. Agar organisasi mudah dijalankan, maka strukturnya dibuat ramping dan sederhana. Oleh karenanya organisasi hanya terdiri dari Ketua, Sekretaris, Bendahara, dan Juru Pungut.

2. Tugas Ketua adalah:

- melakukan komunikasi dengan petugas kebersihan kecamatan untuk pengambilan sampah warga di Dusun Merce, Desa Salut.

- Memantau dan melakukan koordinasi pelaksanaan program kebersihan lingkungan.

- Memantau pelaksanaan pengumpulan iuran retribusi.

3. Tugas Sekretaris adalah membantu Ketua dalam implementasi program kebersihan lingkungan.

4. Tugas Bendahara adalah melakukan pengadministraian aliran dana (masuk dan keluar), memegang kas/keuangan, dan menerima-mengeluarkan dana.

5. Tugas Juru Pungut adalah mengumpulkan iuran dana retribusi dari anggota secara periodik, dan menyerahkannya kepada Ketua Kelompok. 


\section{Elastisitas - Jurnal Ekonomi Pembangunan}

Vol. 2 No. 1, Maret 2020

6. Warga dihimbau untuk ikut dalam program kebersihan lingkungan pemukiman secara sukarela.

\section{- Mobilisasi}

Partisipasi warga dalam menangani sampah untuk program kebersihan lingkungan pemukiman adalah:

1. Sampah RT dikumpulkan di rumah masing-masing.

2. Wadah menyiapkan tempat sampah berupa karung plastik.

3. Setiap Jumat sampah warga diletakkan di pinggir jalan.

4. Membayar iuran retribusi sampah secara periodik

\section{- Pelaksanaan}

Program kebersihan lingkungan pemukiman dimulai pada Januari 2018 (telah bejalan 8 bln yang lalu pada saat wawancara).

1. Kepesertaan dalam program

- Kepesertaan dalam program bersifat sukarela dan tanpa biaya

- Pencatatan nama setiap peserta program.

- Bersedia membayar iuran retribusi sampah sebesar Rp 2.000 per minggu.

- Menyiapkan karung plastik sebagai wadah tempat sampah

- Penyampaian kewajiban dan haknya sebagai peserta program

- Keanggotaan akan hilang jika warga yang bersangkutan tidak membayar iuran retribusi.

2. Penanganan sampah

- Sampah dikumpulkan dalam karung plastik di masing-masing RT.

- Setiap Jumat, sampah yang terkumpul diletakkan di pinggir jalan.

- Setiap Jumat, petugas kebersihan kecamatan/sopir truk menganggkat sampah ke dalam truk, dan meletakkan kembali karung palstik itu.

- Pemberian insentif sebesar Rp 300 ribu setiap kali angkut dengan sistem cash and carry.
- Warga akan mengambil karung plastiknya masing-,masing untuk digunakan kembali.

3. Pemungutan iuran retribusi sampah

- Juru pungut akan menarik retribusi sampah pada hari Rabu-Kamis

- Juru pungut akan mendatangi rumah setiap warga yang ikut dalam program kebersihan

- Juru pungut akan mencatat nama dan besarnya iuran yang diserahkan warga.

- Jika warga tidak berada di rumah, maka iuran tersebut dapat dititipkan pada Ketua RT-nya

- Juru pungut menyetor hasil iuran retribusi kepada Ketua

- Ketua akan menyerahkan dana retribusi kepada Bendahara

- Hasil

a. Jumlah warga yang berpartisipasi dalam program kebersihan lingkungan pemukiman sebanyak 297 RT dari 491 RT yang ada. Jadi tingkat partisipasi masyarakat cukup tinggi, yaitu sebesar $60,5 \%$. Program ini merupakan inisiatif masyarakat setempat, yaitu hanya terdapat di Dusun Merce, Desa Salut. Sebagai Kepala Lingkungan Dusun Merce, pernah mengusulkan agar program yang sama dilakukan pula pada dusun-dusun lainnya. Namun tidak ada respon dari Kepala Desa, sehingga dusun lainnya, tidak ada program tersebut.

b. Upaya penanganan sampah dilakukan secara partisipatif. Warga peserta program dimudahkan dalam hal pembuangan sampah. Sementara bagi warga yang belum ikut dalam program, penanganan sampah RT-nya dilakukan sendiri, tidak boleh penumpuk sampahnya di pinggir jalan, dan atau membuang ke sungai. Kepada warga telah diinformasikan awig-awig tentang penanganan sampah, yaitu;

1. Warga mengumpulkan sampahnya maing-masing dalam suatu wadah. 


\section{Elastisitas - Jurnal Ekonomi Pembangunan}

Vol. 2 No. 1, Maret 2020

2. Dilarang membuang sampah ke jalan, dan atau ke sungai, serta diberikan sanksi jika membuang sampah ke jalan dan sungai.

3. Setiap Jumat, warga meletakkan sampah (harian yang terkumpul) dipinggir jalan agar mudah diangkut oleh petugas kebersihan kecamatan.

4. Setiap warga (yang ikut program penanganan sampah) membayar retibusi sampah sebesar Rp 2.000 per minggu.

Sejak diberlakukannya awiq-awig tersebut lingkungan pemukiman bebas sampah. Warga tidak lagi menumpuk sampahnya di pinggir jalan, dan atau membuangnya ke sungai.

c. Telah terbentuk kelompok/organisasi yang bertugas untuk menata kelola masalah sampah warga. Organisasi ini mampu membangun partisipasi dan memobilisasi sumberdaya masyarakat dengan efektif untuk melaksanakan program kebersihan lingkungan pemukiman. Selain itu, melalui organisasi tersebut, telah tersusun kesepakatan yang dituangkan menjadi awiq-awiq kampung, dan menjadi arahan kepada setiap warga dalam menangani masalah sampah.

d. Warga merasakan manfaat adanya program kebersihan lingkungan pemukiman. Lingkungan menjadi bersih dan bebas dari sampah. Tidak ada sampah berserakan di pemukiman, menumpuk di jalan dan dibuang ke sungai. Membandingkan antara nominal harga lingkungan sebesar Rp 8.000 per bulan dan rata-rata penghasilan mereka sebesar $\mathrm{Rp}$ $1.539,17$ ribu per bulan, maka ratio harga lingkungan sebesar $0,52 \%$ dari penghasilan. Artinya bahwa harga lingkungan sangat kecil dibandingkan dengan kemampuan bayar (ability to pay, ATP) warga.

Dari sisi benefit-cost, manfaatnya jauh lebih besar dibandingkan dengan biaya. Meskipun manfaat dari keberadaan program kebersihan lingkungan tidak dapat dikuantifikasi, namun warga merasakan manfaatnya jauh lebih besar dibandingkan dengan harga lingkungan. Manfaat itu antara lain, warga merasa nyaman karena lingkungan pemukiman yang bersih, warga tidak lagi repot menangani sampah domestiknya sehingga waktunya bisa dikonversi untuk kegiatan produktif, persepsi dan perilaku warga terhadap lingkungan menjadi lebih baik.

e. Kegiatan yang belum dilakukan oleh organisasi adalah melakuklan evaluasi terhadap hasil program kebersihan lingkungan. Evaluasi secara individu telah dilakukan, tapi tidak ada langkah-langkah atau tindak lanjutnya dari hasil penilaian. Evaluasi bersama melalui dialog antar warga penting dilakukan karena 2 alasan;

1. Menilai capaian dan target sehingga ada upaya untuk mengidentifikasi kendala dalam pelaksanaan program, menyusun alternatif langkah-langkah tindakan, dan memperkuat faktor yang dapat mendorong kesuksesan program. Dialog pada akhirnya akan menghasilkan kesepakatan baru dan rencana implementasinya yang memerlukan partisipasi masyarakat.

Kendala yang muncul di lapangan adalah mobilisasi sumberdaya, dimana kurangnya tenaga Juru Pungut untuk pengumpulan iuran retribusi warga secara periodik. Langkah solusi yang dilakukan adalah merekrut anakanak/remaja sekolah, dan mereka mendapat insentif Rp 20.000 per orang. Dengan demikian hasil dialog akan memperbaiki program dan menjamin progresi capaian.

2. Kegiatan dapat berjalan secara siklik sehingga menjamin kontinuitas pastisipasi masyarakat. Persoalan krusial dalam membangun partisipasi adalah kontinuitas dan komitmen masyarakat. Melalui dialog, kontinuitas dan komitmen masyarakat bisa diperbaharui (update) dan ditingkatkan (upgrade) karena muncul aspirasi baru.

\section{KESIMPULAN DAN SARAN}

a. Kesimpulan

1) Harga lingkungan relatif murah, harganya tidak ditentukan melalui mekanisme pasar tapi berdasarkan kesepakatan. 


\section{Elastisitas - Jurnal Ekonomi Pembangunan}

Vol. 2 No. 1, Maret 2020

Dibandingkan dengan rata-rata penghasilan warga, harga tersebut sangat kecil (di bawah $1 \%$ ). Artinya, harga lingkungan tersebut jauh dari harga idealnya, yaitu 2,5\% dari ratarata penghasilan (ability to pay, ATP) warga.

2) Dalam lingkup dusun, tingkat partisipasi masyarakat cukup tinggi, yaitu sebesar 60,5\%.

3) Persepsi dan perilaku masyarakat terhadap lingkungan semakin baik, masyarakat tidak lagi membuang sampah di pinggir jalan, dan atau ke sungai.

4) Telah terbentuk kelompok/organisasi yang melahirkan awiq-awiq kampung, dan menjadi arahan kepada setiap warga dalam menangani masalah sampah. Organisasi lokal ini mampu membangun partisipasi dan memobilisasi sumberdaya masyarakat secara efektif.

b. Saran

1) Perlu adanya kegiatan evaluasi hasil secara kolektif untuk menilai pencapaian, mengidentifikasi kendala dan faktor pendorong untuk menjamin kontinuitas partisipasi masyarakat.

2) Diseminasi model dalam menangani masalah sampah di tempat lain.

\section{DAFTAR PUSTAKA}

Dasgupta, Aniruddha and Victoria A. Beard. 2007. Community Driven Development, Collective Action and Elite Capture in Indonesia. Development and Change 38(2): 229-249 (2007). Institute of Social Studies 2007. Blackwell Publishing. http://geo.ugm.ac.id/wpcontent/files/Community Driven Develo pment Collective Action.pdf - 18 $\underline{\text { Mei } 2013}$
Figueroa, Maria Elena; D. Lawrence Kincaid; Manju Rani; and Gary Lewis. 2002. Communication for Social Change: An Integrated Model for Measuring the Process and Its Outcomes. The Rockefeller Foundation. Paper. http://

www.communicationforsocialchange. org/pdf/socialchange.pdf - 15 Mei 2013.

Hanley, N. And C.L. Spash. 1993. Cost Benefit Analysis and The Environment. Departement of Economics University of Stirling Scotland.

Harley, N. and CL. Spash. 1993. Cost Benefit Analysis and The Environment. Departement Of Economics University of Stiring Scotland.

Holzinger, Katharina. 2003. The Problems of Collective Action: A New Approach. Preprints aus der Max-PlanckProjektgruppe Recht der Gemeinschaftsgüter, Bonn. Paper. http://academic.research.microsoft.co m/Paper/12101463 - 18 Mei 2013

Howard, Michael. 2001. Public Sector Economics for Developing Countries. University of the West Indies Press. Jamaica.

Leach, John. 2004. A Course in Public Economics. Cambridge University Press

Myles, Gareth D. 2001. Public Economics. Cambridge University Press.

Olson, Mancur. 1975. The Logic of Collective Action: Public Goods and the Theory of Groups. Harvard University Press.

Pearce, David W. and R. Kerry Turner. 1990. Economics of Natural Resources and The Environment. Harvester Wheatsheaf. London.

Tietenberg, Thomas H. 1988. Environmental and Natural Resource Economics. Second Edition. Scott, Foresman and Company. London. 


\section{Elastisitas - Jurnal Ekonomi Pembangunan}

Vol. 2 No. 1, Maret 2020

Wade, Robert. 1987. The Management of Common Property Resources: Collective Action as an Alternative to Privatisation or Stat. Regulation. Cambridge Journal of Economics 1987, 11, 95-106.

http://ideas.repec.org/a/oup/cambje/v1 1y1987i2p95-106.html - 18 Mei 2013 